\title{
Pemberian PGPR Indigen untuk Pertumbuhan Kacang Tanah (Arachis hypogaea L.) Varietas Lokal Tuban pada Media Tanam Bekas Tambang Kapur
}

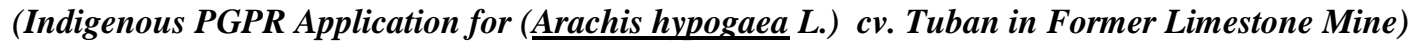 \\ Hesti Kurniahu ${ }^{1 *}$, Sriwulan ${ }^{1}$, dan Riska Andriani ${ }^{1}$ \\ ${ }^{1}$ Program Studi Biologi, FMIPA,Universitas PGRI Ronggolawe Tuban \\ Jl. Manunggal no. 61 Tuban Jawa Timur Indonesia \\ *Email korespondensi: hestiku.hk@gmail.com
}

Diterima 27 Agustus 2018 / Disetujui 28 Oktober 2018

\begin{abstract}
Peanut (Arachis hypogaea L.) cv. Tuban is one of the cultivated plants can be planted on limestone mines former because it has high adaptation to dry and alkali conditions. Biology, physics and chemistry of limestone mined land have low soil fertility. One of the efforts to improve its fertility is use an adaptive biofertilizer on the condition of the limestone former. The purpose of this study was to determine the potential use of PGPR from pioneer plants that grow on ex-limestone mines on vegetative growth of peanut (Arachys hypogaea L.) cv. Tuban in the limestone planting media. This study used a completely randomized design (CRD) with four treatments (25\%, 50\%, 75\% and 100\%) and one control (0\%) each of five replications. The results of this study indicate that based on the MANOVA test giving various concentrations of PGPR does not have a significant effect on the height and number of plant leaves. While based on correlation statistical tests have a significant correlation to leaf color. The higher the PGPR concentration is given, the more green the leaf color will be, based on the Leaf Color Chart (LCC) scale.
\end{abstract}

Keywords: PGPR, Peanut (Arachis hypogaea L.) cv. Tuban, Pioneer plant, Former Limestone mine

\section{ABSTRAK}

Kacang tanah (A Arachys hypogaea L.) varietas lokal Tuban merupakan salah satu tanaman budidaya yang memiliki potensi ditanam pada lahan marginal bekas tambang kapur karena memiliki adaptasi yang tinggi pada kondisi kering dan alkali. Secara biologi, fisika dan kimia lahan bekas tambang kapur memiliki kesuburan tanah yang rendah. Salah satu upaya untuk meningkatkan kesuburannya adalah dengan menggunakan pupuk hayati yang adaptif pada kondisi lahan bekas tambang kapur. Tujuan dari penelitian ini adalah untuk mengetahui potensi pemanfaatan PGPR dari tanaman pioneer yang tumbuh di lahan bekas tambang kapur terhadap pertumbuhan vegetatif kacang tanah (Arachys hypogaea L.) varietas lokal Tuban pada media tanam bekas tambang kapur. Penelitian ini menggunakan Rancangan Acak Lengkap (RAL) dengan empat perlakuan $(25 \%, 50 \%, 75 \%$ dan 100\%) dan satu kontrol (0\%) masing-masing lima kali ulangan. Hasil penelitian ini menunjukkan bahwa berdasarkan uji MANOVA pemberian berbagai konsentrasi PGPR tidak memberikan pengaruh yang signifikan terhadap tinggi dan jumlah daun tanaman. Sementara berdasarkan uji statistik korelasi Spearman memiliki korelasi yang signifikan terhadap warna daun. Semakin tinggi konsentrasi PGPR yang diberikan menghasilkan warna daun yang semakin hijau berdasarkan skala Leaf Colour Chart (LCC).

Kata kunci: PGPR, kacang tanah (Arachys hypogaea L.) varietas lokal Tuban, tanaman pioneer, bekas tambang kapur.

\section{PENDAHULUAN}

Kacang tanah merupakan salah satu komoditas pertanian yang berpotensi untuk dikembangkan di Indonesia karena merupakan tanaman kacang-kacangan yang memiliki nilai ekonomis tertinggi kedua setelah kedelai (Kasno dan Harnowo, 2014) Salah satu upaya yang dapat dilakukan untuk meningkatkan produktifitas pertanian adalah dengan cara memperluas area budidaya. Namun hal ini terkendala oleh alih fungsi lahan pertanian menjadi lahan non budidaya misalnya sebagai tambang kapur. Menurut Prayudyaningsih dan Sari (2016) kegiatan penambangan kapur memiliki dampak negatif terhadap kualitas tanah. Dampak tersebut berupa hilangnya vegetasi dan lapisan topsoil, menurunnya kesuburan tanah, memadat dan timbulnya sisa galian tanah, $\mathrm{pH}$ dan suhu tanah meningkat, serta menurunnya diversitas mikroba tanah. Kondisi tersebut tidak ideal bagi pertumbuhan tanaman termasuk kacang tanah.

Dalam rangka memaksimalkan upaya pemanfaatan lahan marginal bekas tambang kapur menjadi lahan budidaya kacang tanah diperlukan pemilihan varietas kacang tanah yang adaptif dan pemupukan yang tepat serta ramah 
lingkungan. Kacang tanah (Arachys hypogaea L.) varietas lokal Tuban memiliki sifat yang adaptif terhadap kondisi lahan yang kering dan alkalis seperti bekas tambang kapur (Wijaya, 2011). Menurut Kasno dan Harnowo (2014), kacang tanah (Arachys hypogaea L.) varietas lokal Tuban merupakan salah satu dari tiga varietas lokal unggul selain varietas Jepara dan Bima. Pada tanggal 7 Agustus 2003 kacang tanah (Arachis hypogaea L.) varietas lokal Tuban telah resmi menjadi varietas unggul sesuai SK Mentan No. 398/Kpts/SR.120/8/2003.

Pemanfaatan pupuk hayati juga dapat dilakukan untuk mengoptimalkan pertumbuhan kacang tanah (Arachys hypogaea L.) varietas lokal Tuban. Namun pupuk hayati yang digunakan hendaknya merupakan mikroba yang adaptif terhadap lingkungan tanah bekas tambang kapur. PGPR (Plant Growth Promoting Rhizobacteria) adalah sekelompok bakteri yang dapat berkoloni pada area 1-2 cm sekitar perakaran tanaman (rizosfer). Kelompok bakteri tersebut dapat memberikan dampak positif bagi pertumbuhan tanaman diantaranya sebagai penyedia unsur hara (pupuk hayati), menghasilkan hormon pertumbuhan (zat pengatur tumbuh) dan memiliki sifat antagonis terhadap hama penyakit tumbuhan (Nasib, 2016; Febriyanti et al., 2015). Berdasarkan informasi tersebut sumber PGPR indigen dari tanaman pioneer yang tumbuh di lahan bekas tambang kapur dapat dimanfaatkan sebagai biofertilizer, biostimulan dan bioprotektan pada tanaman termasuk kacang tanah (Arachis hypogaea L.) varietas lokal Tuban.

Tujuan dari penelitian ini adalah untuk mengetahui potensi pemanfaatan PGPR indigen tanaman pioneer terhadap pertumbuhan kacang tanah (Arachys hypogaea L.) varietas lokal Tuban pada media tanam bekas tambang kapur. Hal ini dilakukan sebagai salah satu upaya pemanfaatan lahan marginal berupa lahan bekas tambang kapur untuk meningkatkan produktifitas kacang tanah.

\section{METODE PENELITIAN}

\section{Alat dan Bahan}

Penelitian ini menggunakan beberapa alat yaitu: timbangan, mortar dan pistil, gelas ukur, beaker glass, jirigen, cetok, polybag, gayung plastik, gloves, penggaris, masker, kamera dan leaf colour chart (LCC) merk IRRI. Sedangkan bahan yang digunakan yaitu tanah perakaran tanaman pioneer (Tridax procumbens, Crotalaria mucronata, Mimosa pudica, Imperata cylindrica dan Pteris sp.), buffer fosfat $\mathrm{pH} 7$, aquades, kacang tanah (Arachys hypogaea L.) varietas lokal Tuban, media tanam tanah bekas tambang kapur.

\section{Tahap Persiapan}

Menurut Kurniahu et al., (2017), bibit PGPR diperoleh dengan cara: mengambil masing-masing 50 gram tanah dan akar tanaman pioneer yang tumbuh di lahan bekas tambang kapur Desa Leran Wetan Kecamatan Palang Kabupaten Tuban. Sampel tersebut dimaserasi kemudian dimasukkan ke dalam jirigen dengan ditambahkan bufer fosfat $\mathrm{pH} 7$ dan diinkubasi selama 1 minggu pada suhu ruang.

\section{Tahap Pelaksanaan}

Membuat dosis PGPR seperti yang diinginkan (0\%, $25 \%, 50 \%, 75 \%$ dan $100 \%$ ) dengan cara menambahkan bibit PGPR yang telah diinkubasi selama 1 minggu dengan aquades sesuai dengan dosis yang diinginkan masing-masing sebanyak $50 \mathrm{~mL}$. Merendam bibit kacang tanah (Arachys hypogaea L.) varietas lokal Tuban ke dalam berbagai dosis PGPR selama 1 jam. Menanam bibit kacang tanah yang telah direndam berbagai dosis PGPR ke dalam polybag yang berisi $5 \mathrm{~kg}$ tanah bekas tambang kapur kemudian larutan PGPR yang digunakan untuk merendam biji kacang tanah tersebut disiramkan ke media tanam secara merata. Setiap 2 hari sekali dilakukan penyiraman sebanyak $100 \mathrm{~mL}$ pada masing-masing kacang tanah (Arachys hypogaea L.) varietas lokal Tuban. Pengamatan berupa tinggi, jumlah daun dan warna daun kacang tanah (Arachys hypogaea L.) varietas lokal Tuban dilakukan setiap minggu selama 6 minggu setelah tanam. Selanjutnya untuk mengetahui pengaruh pemberian PGPR terhadap pertumbuhan vegetatif kacang tanah berupa tinggi tanaman dan jumlah daun dilakukan uji statistik Manova sementara uji korelasi Spearman's dilakukan untuk mengetahui hubungan antara pemberian berbagai dosis PGPR terhadap warna daun kacang tanah (Arachys hypogaea L.) varietas lokal Tuban.

\section{HASIL DAN PEMBAHASAN}

\section{Tinggi Tanaman}

Berdasarkan hasil pengamatan selama 6 MST dan uji statistik diketahui bahwa pemberian berbagai konsentrasi larutan PGPR tidak berbeda secara signifikan terhadap rerata tinggi tanaman. Rerata tinggi tanaman yang diamati tiap minggu disajikan dalam Tabel 1 dan Gambar 1 .

Berdasarkan perhitungan statistik diketahui bahwa perlakuan dengan berbagai dosis PGPR (20\%, 50\%, 75\% dan $100 \%$ ) tidak memberikan pengaruh yang signifikan terhadap pertambahan tinggi tanaman kacang tanah (Arachys hypogaea L.) varietas lokal Tuban pada media tanam bekas tambang kapur. Namun demikian berdasarkan Tabel 1 dan Gambar 1 diketahui bahwa sejak 2 MST sampai dengan 6 MST konsentrasi PGPR $75 \%$ memberikan rerata tinggi tanaman paling baik dibandingkan dengan dosis lain $(20 \%, 50 \%, 100 \%)$ dan kontrol $(0 \%)$. Hal ini menunjukkan bahwa PGPR tanaman pioneer dosis $75 \%$ memiliki potensi untuk menghasilkan hormon auksin yang berperan dalam memacu pertumbuhan tanaman kacang tanah (Arachys hypogaea L.) varietas lokal Tuban yang di tanam pada media tambang kapur walaupun hasilnya belum optimal. Menurut Kurniahu et al. (2017) inokulasi PGPR dengan dosis $75 \%$ memicu pertumbuhan tinggi bibit tanaman jahe merah paling optimal. Mekanisme PGPR dalam memacu petambahan tinggi tanaman karena PGPR memiliki kemampuan untuk menghasilkan hormon auksin dalam lingkungan perakaran tumbuhan (Febriyanti et al., 2015). 
Menurut Hidayat (2008) hormon auksin memiliki peran dalam memicu pembelahan sel dan pemanjangan sel meristem sehingga mempercepat penambahan tinggi kacang tanah. Selain itu aplikasi PGPR juga mampu mengoptimalkan penyerapan dan pemanfaatan unsur hara $\mathrm{N}$ yang diperlukan dalam pertumbuhan vegetatif tanaman kacang tanah (Arachys hypogaea L.) varietas lokal Tuban (Marom et al. 2017).

Pemberian berbagai konsentrasi PGPR untuk pertumbuhan kacang tanah (Arachys hypogaea L.) varietas lokal Tuban pada media tanam bekas tambang kapur dalam penelitian ini tidak berjalan optimal dimungkinkan karena komposisi tanaman pioneer sumber PGPR yang mengandung zat alelopat. Tanaman alang-alang (Imperata cylindrica) sebagai salah satu komposisi PGPR ternyata memiliki senyawa alelokemis yang dapat menghambat pertumbuhan tanaman lain. Menurut Kamsurya (2013) pemberian ekstrak alang-alang dari seluruh bagian tanamannya termasuk akar mampu menghambat pertambahan tinggi tanaman jagung. Kandungan fenolat pada alang-alang mampu menghambat difusi air dan oksigen ke dalam tanaman sehingga pembelahan dan perbesaran sel terhambat.

\section{Jumlah Daun}

Berdasarkan pengamatan selama 6 MST dan uji statistik diketahui bahwa pemberian berbagai konsentrasi PGPR tidak berpengaruh secara signifikan terhadap rerata jumlah daun tanaman kacang tanah (Arachys hypogaea L.) varietas lokal Tuban yang di tanam pada media tambang kapur. Rerata jumlah daun yang diamati tiap minggu disajikan dalam Tabel 1 dan Gambar 1.

Tabel 1. Rerata tinggi tanaman dengan aplikasi berbagai konsentrasi PGPR pada berbagai waktu pengamatan

\begin{tabular}{lllllll}
\hline \multirow{2}{*}{ Perlakuan } & \multicolumn{6}{l}{ Minggu ke- } \\
\cline { 2 - 7 } & 1 & 2 & 3 & 4 & 5 & 6 \\
\hline $0 \%$ & 1.84 & 6.36 & 8.62 & 10 & 12.6 & 16.1 \\
$25 \%$ & 2.73 & 7.16 & 9.88 & 11.6 & 13.9 & 17.6 \\
$50 \%$ & 2.1 & 5.41 & 9.88 & 11.3 & 12.6 & 16.2 \\
$75 \%$ & 1.65 & 7.29 & 10.6 & 11.9 & 14.9 & 19.4 \\
$100 \%$ & 1.77 & 5.29 & 7.96 & 10.8 & 12.1 & 18 \\
\hline
\end{tabular}



Gambar 1. Rerata tinggi tanaman kacang tanah (Arachys hypogaea L.) varietas lokal Tuban pada media tanam bekas tambang kapur dengan aplikasi berbagai konsentrasi PGPR. 
Tabel 1. Rerata jumlah daun dengan aplikasi berbagai konsentrasi PGPR pada berbagai waktu pengamatan

\begin{tabular}{lllllll}
\hline \multirow{2}{*}{ Perlakuan } & \multicolumn{7}{l}{ Minggu ke- } \\
\cline { 2 - 7 } & 1 & 2 & 3 & 4 & 5 & 6 \\
\hline $0 \%$ & 0 & 3.35 & 5.13 & 6.13 & 6.70 & 10.90 \\
$25 \%$ & 0 & 3.95 & 5.50 & 5.93 & 7.27 & 11.50 \\
$50 \%$ & 0 & 3.68 & 5.32 & 6.30 & 7.33 & 10.33 \\
$75 \%$ & 0 & 3.80 & 5.40 & 6.23 & 8.00 & 12.20 \\
$100 \%$ & 0 & 3.63 & 5.22 & 6.30 & 7.20 & 11.63 \\
\hline
\end{tabular}

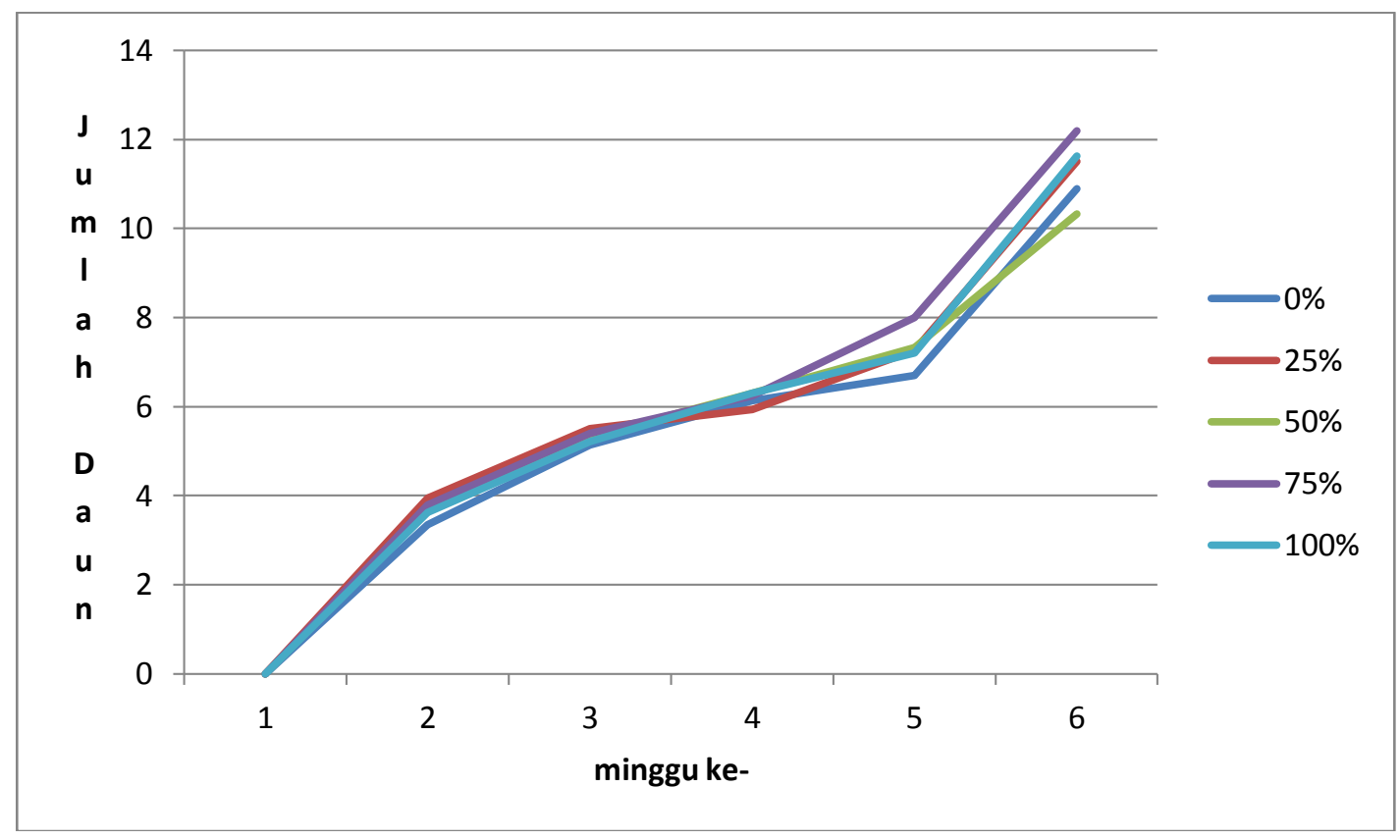

Gambar 2. Rerata jumlah daun kacang tanah (Arachys hypogaea L.) varietas lokal Tuban pada media tanam bekas tambang kapur dengan aplikasi berbagai konsentrasi PGPR

Tabel 2 dan Gambar 2 diketahui bahwa sejak 4 MST konsentrasi PGPR 75\% memberikan rerata jumlah daun kacang tanah paling tinggi dibandingkan dengan perlakuan lain (konsentrasi 25\%, 50\%, 100\%) dan kontrol (0\%). Hal ini menunjukkan bahwa PGPR dengan konsentrasi $75 \%$ berpotensi untuk digunakan sebagai agen pemicu pertumbuhan tanaman termasuk pertambahan jumlah daun. Menurut Iswati (2012) pemberian PGPR dengan dosis yang tepat dapat memacu pertambahan jumlah daun yang optimal karena mampu memproduksi dan mengubah konsentrasi fitohormon serta memobilisasi dan memfasilitasi penyerapan unsur hara yang diperlukan dalam pertumbuhan tanaman termasuk peningkatan jumlah daun.

Menurut hasil uji statistik diketahui bahwa pemberian berbagai konsentrasi PGPR tidak memberikan pengaruh secara signifikan terhadap jumlah daun kacang tanah kacang tanah (Arachys hypogaea L.) varietas lokal Tuban pada media tanam bekas tambang kapur dengan aplikasi berbagai konsentrasi PGPR dalam pengamatan selama 6 MST. Kemungkinan penyebabnya sama dengan yang terjadi dengan tinggi tanaman kacang tanah yaitu pemakaian alangalang sebagai salah satu komposisi PGPR. Menurut Yanti dkk. (2016) kandungan fenolat pada alang-alang mampu menghambat difusi air dan oksigen ke dalam tanaman sehingga pembelahan dan perbesaran sel terhambat sehingga menghambat pertumbuhan semai akasia termasuk menghambat pertambahan jumlah daun.

\section{Warna Daun}

Berdasarkan uji statistik pada warna daun kacang tanah (Arachys hypogaea L.) varietas lokal Tuban diketahui bahwa pemberian berbagai konsentrasi $(0 \%, 25 \%$, $50 \%, 75 \%$ dan $100 \%$ ) memiliki hubungan yang signifikan dengan tingkat korelasi positif yang cukup terhadap warna daun kacang tanah. Kisaran skala warna daun yang diamati dapat dilihat di Tabel 3.

Berdasarkan uji statistik diketahui bahwa pemberian berbagai konsentrasi PGPR memiliki korelasi positif 
Tabel 3. Skala warna daun berdasarkan leaf colour chart (LCC) dengan aplikasi berbagai konsentrasi PGPR pada berbagai waktu pengamatan

\begin{tabular}{llllllll}
\hline \multirow{2}{*}{ Perlakuan } & \multicolumn{2}{l}{ Minggu ke- } & & & \\
\cline { 2 - 8 } & 1 & 2 & 3 & 4 & 5 & 6 \\
\hline $0 \%$ & $2-3$ & 2 & $2-3$ & 2 & $1-2$ & $1-2$ & $2-3$ \\
$25 \%$ & $2-3$ & $2-4$ & $3-4$ & $2-3$ & $2-3$ & $1-4$ & $2-4$ \\
$50 \%$ & $2-3$ & $2-3$ & $2-3$ & $2-3$ & 2 & $2-3$ & $2-4$ \\
$75 \%$ & $2-3$ & $3-4$ & $3-4$ & $3-4$ & $2-4$ & $2-3$ & \\
$100 \%$ & 3 & $3-4$ & $3-5$ & $2-4$ & \\
\hline
\end{tabular}

terhadap warna daun, artinya semakin tinggi konsentrasi PGPR yang diberikan maka skala warna daun akan semakin besar atau secara visual warna daun semakin hijau. Pengukuran warna daun dilakukan dengan menggunakan Leaf Colour Chart (Bagan Warna Daun). Menurut Wahid (2003) warna daun dipengaruhi oleh kadar N dalam tanaman karena berperan pada pembentukan klorofil.

Nitrogen merupakan salah satu unsur hara makro yang diperlukan oleh tanaman sehingga keberadaannya mutlak diperlukan oleh tanaman dalam pertumbuhannya, membentuk protein dan asam nukleat serta membentuk klorofil untuk fotosintesis. Menurut Fitriyanti (2017) sekitar 90-95\% nitrogen dalam tanah terikat dalam bentuk material organik, dan di udara nitrogen berada dalam bentuk $\mathrm{N}_{2}$. Sementara tanaman hanya mampu menyerap unsur $\mathrm{N}$ dalam bentuk ion $\mathrm{NO}_{3}^{-}$dan $\mathrm{NH}_{4}^{-}$. Untuk mengubahnya diperlukan bakteri penambat nitrogen. Pada tanaman Leguminaceae termasuk kacang tanah (Arachys hypogaea L.) memiliki bakteri Rhizobium sp. yang bersimbiosis pada akar dan membentuk bintil akar untuk mengikat nitrogen (Hidayat, 2008). Berdasarkan hasil penelitian ini diketahui bahwa pemberian berbagai konsentrasi PGPR berkorelasi positif terhadap warna daun, sehingga hal ini diduga menjadi penyebab perbedaan warna daun antara kontrol dan perlakuan. Menurut Nasib dkk. (2016) dan Iswati (2012) terdapat beberapa jenis bakteri dalam PGPR yang dapat memobilisasi dan menyediakan unsur hara salah satunya yaitu bakteri penyedian unsur $\mathrm{N}$ non simbiotik yang dapat dimanfaatkan oleh tanaman dalam hal ini adalah kacang tanah (Arachys hypogaea L.) varietas lokal Tuban.

\section{KESIMPULAN}

Perlakuan perendaman biji dan penyiraman dengan berbagai dosis PGPR tanaman pioneer bekas tambang kapur (Tridax procumbens, Crotalaria mucronata, Mimosa pudica, Imperata cylindrica dan Pteris sp.) tidak memberikan pengaruh yang signifikan terhadap tinggi dan jumlah daun kacang tanah (Arachys hypogaea L.) varietas lokal Tuban pada media tanam bekas tambang kapur. Tetapi pemberian berbagai konsentrasi PGPR memiliki korelasi positif terhadap warna daun. Semakin tinggi konsentrasi PGPR yang diberikan maka skala warna daun pada Leaf Colour Chart (LCC) semakin tinggi atau secara visual semakin hijau.

\section{UCAPAN TERIMA KASIH}

Terimakasih kepada Kemenristekdikti yang telah menyediakan dana, Siti Nurfaidah sebagai technical support, Kepala Lab, dan Laboran Biologi Universitas PGRI Ronggolawe Tuban serta semua pihak yang telah membantu dalam penelitian ini.

\section{DAFTAR PUSTAKA}

Febriyanti, L. Echa., M. Martosudiro, T. Hadiastono. 2015. Pengaruh Plant Growth Promoting Rhizobacteria (PGPR) terhadap Infeksi Peanut Stripe Virus (PStV), Pertumbuhan dan Produksi Kacang Tanah (Arachis hypogaea L. ) Varietas Gajah. Jurnal HPT. 3(1):84-92.

Fitriyanti, D. 2017. Karakterisasi Bakteri Pelarut Fosfat dan Penambat Nitrogen dari Area Penambangan Batu Kapur. Tesis. Institut Pertanian Bogor. Bogor.

Hidayat, N. 2008. Pertumbuhan dan Produksi Kacang Tanah (Arachis hypogeal L.) Varietas Lokal Madura pada Berbagai Jarak Tanam dan Dosis Pupuk Fosfor. Jurnal Agrivigor. (1):55-64.

Iswati, R. 2012. Pengaruh Formula Dosis PGPR Asal Perakaran Bambu terhadap Pertumbuhan Tanaman Tomat (Solanum lycopersicum Lyn.). Jurnal Agroteknotropika 1(1):9-12.

Kamsurya, M. Yani. 2013. Pengaruh Senyawa Alelopati dari Alang-alang (Imperata cylindrica) terhadap Pertumbuhan dan Perkembangan Tanaman Jagung (Zea Mays L.). Jurnal Bimafika. 5:566-569.

Kasno, A., D. Harnowo. 2014. Karakteristik Kacang Tanah dan Adopsinya oleh Petani. Iptek Tanaman Pangan. 9(1):13-23.

Kurniahu, H., Sriwulan, R. Andriani. 2017. Aplikasi PGPR Rhizhosfer Graminae terhadap Pertumbuhan Jahe Merah (Zingiber officinale var. Rubrum.). Jurnal Pena Sains. 4(2):133-137. 
Marom, N., Rizal, M. Bintoro. 2017. Uji Efektifitas Waktu Pemberian dan Konsentrasi PGPR (Plant Growth Promoting Rhizobacteria) terhadap Produksi dan Mutu Benih Kacang Tanah (Arachis hypogea L.). Jurnal Agriprima. 1(5):191-202.

Nasib, S.B., K. Suketi, W.D. Widodo. 2016. Pengaruh Plant Growth Promoting Rhizobacteria Terhadap Bibit dan Pertumbuhan Awal Pepaya. Buletin Agrohorti. 4(1):63-69.

Prayudyaningsih, R., R. Sari. 2016. Aplikasi Fungi Mikoriza Arbuskula (FMA) dan Kompos untuk Meningkatkan Pertumbuhan semai Jati (Tectona grandis Linn.f.) pada Media Tanah Bekas tambang Kapur. Jurnal Penelitian Kehutanan Wallacea. 5(1):37-46.

Wahid, A. S. 2003. Peningkatan Efisiensi Pupuk Nitrogen pada Padi Sawah dengan Metode Bagan Warna Daun. Jurnal Litbang Pertanian. 22(4):156-161.

Wijaya, A. 2011. Pengaruh Pemupukan dan Pemberian Kapur terhadap Pertumbuhan dan Daya Hasil Kacang Tanah (Arachis hypogaea L.). Disertasi. Institut Pertanian Bogor. Bogor.

Yanti, M., Indriyanto, Duryat. 2016. Pengaruh Zat Alelopati dari Alang-alang terhadap Pertumbuhan Semai Tiga Spesies Akasia. Jurnal Sylva Lestari. 4(2):27-38. 